\title{
Effect of silage type and energy concentration on conjugated linoleic acid (CLA) in milk fat from dairy cows
}

\author{
T.S. Nielsen ${ }^{1}$, K. Sejrsen ${ }^{1,3}$, H. R. Andersen ${ }^{1}$, P. Lund ${ }^{2}$ \\ and E.M. Straarup ${ }^{2}$ \\ ${ }^{1}$ Department of Animal Nutrition and Physiology, Danish Institute of Agricultural Sciences, \\ Research Centre Foulum \\ P.O. Box 50, DK-8830 Tjele, Denmark \\ ${ }^{2}$ BioCentrum-DTU, DK-2800 Lyngby, Denmark
}

\begin{abstract}
40 lactating cows were fed either clovergrass or maize silage and a low or high dietary energy concentration in a $2 \times 2$ factorial design. The maize silage diets rich in starch and linoleic acid resulted in a higher content of c9t11 and t10c12 CLA in milk fat than the grass silage diets. A high energy concentration plus maize silage led to a pronounced shift in the biohydrogenation pathway of linoleic acid, the highest t10c12 CLA content and lowest milk fat percentage. Energy concentration had no effect on milk fat CLA content or milk fat percentage in grass silage fed cows.
\end{abstract}

KEY WORDS: CLA, biohydrogenation, silage, energy concentration, milk fat depression

\section{INTRODUCTION}

The dietary supply and composition of polyunsaturated fatty acids (PUFA) especially linoleic acid (C18:2) and linolenic acid (C18:3) together with ruminal conditions for biohydrogenation of unsaturated fatty acids are major determinants of milk fat CLA concentration (Griinari and Baumann, 1999). Since oilseeds contain considerable amounts of PUFA the effect of dietary supplementation with oilseeds and plant oils on milk fat CLA have been intensively investigated, but less is known about the effect of forage differing in PUFA composition. Furthermore, it is well known that the extent of biohydrogenation is influenced by the energy concentration of the diet (Doreau and Ferley, 1994). Therefore the aim of the present work was to investigate how two commonly used forage types clovergrass silage and maize

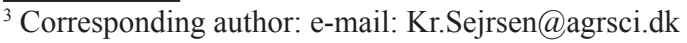


silage differing in composition of $\mathrm{C} 18: 2$ and $\mathrm{C} 18: 3$ combined with a relatively low or relatively high dietary energy concentration affected the content of cis-9 trans-11 (c9t11) and trans-10 cis-12 (t10c12) CLA in milk fat from dairy cows.

\section{MATERIAL AND METHODS}

40 Holstein Friesian cows blocked in 10 blocks according to parity, days in lactation and milk yield were randomly assigned to one of four TMR diets in a $2 \times 2$ factorial design with two silage types (clovergrass or maize) and two energy concentrations (low or high). The ingredients and chemical composition of the diets fed ad libitum are shown in Table 1. Maize silage diets had the highest content of C18:2 and starch while grass silage diets had highest content of C18:3. Feed intake was recorded daily. During the 6-week experimental period milk yield was measured twice weekly and milk samples for fatty acid analyses were obtained every second week and analysed by gas chromatography at the Biochemistry and Nutrition Group, BioCentrum-DTU, Lyngby (Denmark).

Statistical analyses were performed in SAS (version 8.02) using the GLM procedure, and results represent the last 4 weeks of the experimental period. For milk yield and energy corrected milk yield (ECM) pre-experimental milk yield and ECM was used as a covariate.

Table 1. Ingredients and chemical composition of the TMR diets

\begin{tabular}{|c|c|c|c|c|}
\hline \multirow{3}{*}{$\begin{array}{l}\text { Silage type } \\
\text { Energy level }\end{array}$} & \multicolumn{4}{|c|}{ Diet $^{1}$} \\
\hline & \multicolumn{2}{|c|}{ G } & \multicolumn{2}{|c|}{$\mathrm{C}$} \\
\hline & $\mathrm{L}$ & $\mathrm{h}$ & $\mathrm{L}$ & $\mathrm{h}$ \\
\hline \multicolumn{5}{|l|}{$\%, D M$ basis } \\
\hline maize silage & - & - & 68.8 & 52.0 \\
\hline clovergrass silage & 72.7 & 52.7 & - & - \\
\hline barley & - & 18.3 & - & 16.2 \\
\hline rapeseed cake & 27.0 & 28.3 & 30.2 & 30.6 \\
\hline mineral mix, type I & 0.19 & 0.54 & 0.89 & 1.14 \\
\hline vitamin mix & 0.16 & 0.14 & 0.14 & 0.12 \\
\hline \multicolumn{5}{|l|}{ Chemical composition } \\
\hline DM, \% & 35.0 & 41.7 & 38.9 & 45.5 \\
\hline crude protein & 20.9 & 19.9 & 15.4 & 15.8 \\
\hline crude fat & 6.5 & 6.6 & 6.9 & 6.9 \\
\hline starch & 0.4 & 10.1 & 20.8 & 24.4 \\
\hline NDF & 33.8 & 29.0 & 33.4 & 29.2 \\
\hline C18:2 & 1.1 & 1.4 & 1.8 & 1.9 \\
\hline $\mathrm{C} 18: 3$ & 0.96 & 0.85 & 0.52 & 0.53 \\
\hline sum of fatty acids & 5.2 & 5.6 & 6.2 & 6.3 \\
\hline $\mathrm{NE}^{2}, \mathrm{MJ} / \mathrm{kg} \mathrm{DM}$ & 7.57 & 7.97 & 7.18 & 7.57 \\
\hline
\end{tabular}

${ }^{1}$ diets: $\mathrm{G}$ - grass silage, $\mathrm{C}$ - maize silage, 1 - low energy, $\mathrm{h}$ - high energy

${ }^{2}$ Net energy of lactation is based on Danish feed units (FU) (7.89 MJ NE=1 FU) 


\section{RESULTS AND DISCUSSION}

Cows receiving high energy diets had a significantly higher dry matter intake (DMI) than cows on low energy diets (Table 2), but there were no difference in milk yield between the four diets. ECM yield was lower in maize silage fed cows due to a lower milk fat percentage (Table 2). Cows receiving maize silage had the highest intake of C18:2 acid while cows receiving grass silage had the highest intake of C18:3 acid due to the difference in PUFA composition of maize and grass silage (data not shown).

Table 2. Feed intake, milk yield and fatty acids (g/100 g FAME) in milk from cows fed grass or maize silage with low or high concentration of concentrate

\begin{tabular}{|c|c|c|c|c|c|c|c|c|}
\hline \multirow{3}{*}{$\begin{array}{l}\text { Silage type }(\mathrm{S}) \\
\text { Energy level (E) }\end{array}$} & \multicolumn{4}{|c|}{ Diet $^{1}$} & \multirow{3}{*}{ SEM } & \multirow{2}{*}{\multicolumn{3}{|c|}{$\mathrm{P}<^{2}$}} \\
\hline & \multicolumn{2}{|c|}{$\mathrm{G}$} & \multicolumn{2}{|r|}{$\mathrm{C}$} & & & & \\
\hline & 1 & $\mathrm{~h}$ & 1 & $\mathrm{~h}$ & & $\mathrm{~S}$ & $E$ & $\mathrm{~S} \times \mathrm{E}$ \\
\hline \multicolumn{9}{|l|}{ Feed intake } \\
\hline DMI, kg/d & 18.4 & 19.4 & 18.4 & 20.0 & 0.4 & 0.49 & 0.005 & 0.43 \\
\hline $\mathrm{C} 18: 2, \mathrm{~g} / \mathrm{d}$ & 211 & 275 & 345 & 390 & 7 & 0.001 & 0.001 & 0.19 \\
\hline $\mathrm{C} 18: 3, \mathrm{~g} / \mathrm{d}$ & $180^{\mathrm{a}}$ & $167^{\mathrm{b}}$ & $105^{\mathrm{c}}$ & $114^{\mathrm{c}}$ & 3 & 0.001 & 0.50 & 0.002 \\
\hline total fat, $\mathrm{g} / \mathrm{d}$ & 969 & 1100 & 1210 & 1328 & 26 & 0.001 & 0.001 & 0.82 \\
\hline \multicolumn{9}{|l|}{ Milk yield } \\
\hline milk yield, $\mathrm{kg} / \mathrm{d}^{3}$ & 24.4 & 25.6 & 23.4 & 23.7 & 1.02 & 0.17 & 0.49 & 0.67 \\
\hline $\mathrm{ECM}, \mathrm{kg} / \mathrm{d}^{3}$ & 25.1 & 26.7 & 22.3 & 22.0 & 1.00 & 0.011 & 0.54 & 0.37 \\
\hline fat, $\%$ & 4.06 & 4.16 & 3.42 & 3.12 & 0.19 & 0.001 & 0.58 & 0.30 \\
\hline fat yield, $\mathrm{kg} / \mathrm{d}$ & 0.99 & 1.07 & 0.77 & 0.74 & 0.06 & 0.001 & 0.65 & 0.34 \\
\hline \multicolumn{9}{|l|}{ Milk fatty acids } \\
\hline $18: 1$, trans -11 & $1.73^{\mathrm{a}}$ & $1.78^{\mathrm{a}}$ & $2.91^{\mathrm{b}}$ & $1.78^{\mathrm{a}}$ & 0.25 & 0.03 & 0.04 & 0.03 \\
\hline 18:1, trans -10 & $0.59^{\mathrm{a}}$ & $0.65^{\mathrm{a}}$ & $2.96^{\mathrm{b}}$ & $5.87^{\mathrm{c}}$ & 0.54 & 0.001 & 0.01 & 0.01 \\
\hline$c 9 t 11 \mathrm{CLA}$ & $0.89^{\mathrm{a}}$ & $0.91^{\mathrm{a}}$ & $1.62^{\mathrm{b}}$ & $1.20^{\mathrm{c}}$ & 0.10 & 0.001 & 0.05 & 0.04 \\
\hline$t 10 c 12$ CLA & $0.012^{\mathrm{a}}$ & $0.014^{\mathrm{a}}$ & $0.023^{\mathrm{b}}$ & $0.032^{\mathrm{c}}$ & 0.002 & 0.001 & 0.003 & 0.03 \\
\hline$c 9 t 11$ CLA yield, $\mathrm{g} / \mathrm{d}$ & $8.68^{\mathrm{a}}$ & $9.66^{\mathrm{ab}}$ & $12.20^{\mathrm{b}}$ & $8.79^{a}$ & 0.88 & 0.14 & 0.18 & 0.02 \\
\hline$t 10 c 12$ CLA yield, $\mathrm{g} / \mathrm{d}$ & 0.12 & 0.15 & 0.18 & 0.23 & 0.012 & 0.001 & 0.001 & 0.22 \\
\hline
\end{tabular}

${ }^{1}$ diets: $\mathrm{G}$ - grass silage, $\mathrm{C}$ - maize silage, 1 - low energy, $\mathrm{h}$ - high energy

${ }^{2}$ statistical probabilities of treatment differences. Values represent means for the last 4 weeks of the experimental period and means within row with different superscripts differ according to $\mathrm{P}$ value indicated

${ }^{3}$ for the trait a covariate was included in the analysis

There was an interaction between silage type and energy concentration on milk fat content of both CLA isomers and the two associated trans fatty acids trans-11 $\mathrm{C} 18: 1$ and trans-10 $\mathrm{C} 18: 1$. The $\mathrm{Cl}$ diet resulted in the highest trans-11 C18:1 and c9t11 CLA concentration while cows fed grass silage diets showed the lowest c9t11 CLA and trans-11 C18:1 concentration in milk fat irrespective of the energy level. 
Milk from cows fed the Ch diet had the highest content of t10c12 CLA and trans-10 C18:1 indicating a shift in the biohydrogenation pathway of linoleic acid (Bauman and Griinari, 2001). Feeding maize silage diets seemed to predispose this shift because the $\mathrm{Cl}$ diet also resulted in a significantly higher t10c12 CLA concentration than grass diets, but a low energy concentration was able to attenuate the shift in biohydrogenation pathway of linoleic acid. The Ch treatment also resulted in the lowest milk fat percentage and daily milk fat yield and support previous findings of an elevated t10c12 CLA concentration being associated with milk fat depression (Peterson et al., 2003). Bauman and Griinari (2003) suggested the presence of PUFA together with an altered rumen environment e.g., caused by low fibre diets rich in starch as prerequisites for the production of t10c12 CLA and milk fat depression to occur. This hypothesis is supported by the present results.

\section{CONCLUSIONS}

Maize silage diets were more effective at increasing the c9t11 and t10c12 CLA concentration in milk fat than grass silage diets, and a high energy concentration plus maize silage led to the highest t10c12 CLA concentration and the lowest milk fat percentage. The energy level had no influence on milk fat CLA concentration or milk fat percentage in cows fed grass silage diets, and overall these results support the hypothesis of an interaction between PUFA especially C18:2 and the energy level (starch) in the diet, on the extent and pathway of biohydrogenation and milk fat depression.

\section{REFERENCES}

Baumann D.E., Griinari J.M., 2001. Regulation and nutritional manipulation of milk fat: low-fat milk syndrome. Livest. Prod. Sci 70, 15-29

Bauman D.E., Griinari M.J., 2003. Nutritional regulation of milk fat synthesis. Annu. Rev. Nutr. 23, 203-227

Doreau M., Ferley A., 1994. Digestion and utilisation of fatty acids by ruminants. Anim. Feed Sci. Tech. 45, 379-396

Griinari J.M., Bauman D.E., 1999. Biosynthesis of conjugated linoleic acid and its incorporation into meat and milk. In: M.P. Yurawecz, M.M. Mossoba, J.K.G. Kramer, M.W. Pariza, G.J. Nelson (Editors). Advances in Conjugated Linoleic Acid Research, Vol. 1. AOCS Press, Illinois, pp. $180-200$

Peterson D. G., Matitashvili E. A., Bauman D. E., 2003. Diet-induced milk fat depression in dairy cows results in increased trans-10, cis-12 CLA in milk fat and coordinate suppression of mRNA abundance for mammary enzymes involved in milk fat synthesis. J. Nutr. 133, 3098-3002 